\title{
Contempt of Court in the Perspective of Criminal Law Enforcement
}

\author{
Dr. Hamidah Abdurrachman, S.H., M.H ${ }^{1}$, Dr. Fajar Ari Sudewo, S.H., M.H² \\ Universitas Pancasakti Tegal, Indonesia ${ }^{1,2}$ \\ $\left\{\right.$ h_abdurrachman@upstegal.ac.id ${ }^{1}$,drfajararisudewo@gmail.com² $\}$
}

\begin{abstract}
The latest Draft Criminal Code (RKUHP) dated August 28, 2019 sets out the Contempt of Court in Article 281, that any individual who does not abide by court order or judicial decree issued for the purpose of judicial process, behaves disrespectfully towards judge or the court or attacks judge's integrity or impartiality in court hearing, or unlawfully records, directly publicizes, or allows publication of anything which may affect judge's impartiality in court hearing is subject to criminal imprisonment for maximum 1 year or criminal fine for maximum Rp10,000,000.- Based on the mandate of Act Number 5 of 2004 on the Amendment to Supreme Court Act Number 14 of 1985 on the Supreme Court, Contempt of Court should be set forth in independent Law and Regulation so as not to cause turmoil in the community as the result of criminalization in criminal judicial process.Problems resulted from regulation of Contempt of Court on judicial process are deemed to restrict the rights of law enforcers such as advocates and other justice seekers. When a law enforcer is criticizing the course of a hearing process, it may be categorized into Contempt of Court pursuant to Article 281 RKUHP.
\end{abstract}

Keywords: contempt of court, law enforcement, RKUHP.

\section{Introduction}

The term Contempt of Court in Indonesia is first found in the General Explanatory Note to Act Number 14 of 1985 on the Supreme Court item 4 paragraph 4 explaining that any act, behavior, attitude and speech which may undermine the authority, dignity and honor of a judicial agency may be categorized into and qualified as contempt of judicial agency or Contempt of Court. Based on the General Explanatory Note to Supreme Court Act above, we may understand that "Contempt of Court" regulation is particularly intended to realize assurance of "judicial body's" authority, dignity and honor. In a more concrete form, such assurance is addressed to natural persons who administer and activity process as well as decision of such body [1].

Hasbullah F Syawie states that contempt of court may be defined as an earnest and intentional act deemed embarrassing court's authority and dignity or preventing the court from performing adjudicative process made by litigants or non-litigants.[2] From the two explanations of contempt of court, we may conclude that a criminal act of contempt of court may be committed by anyone whether or not involved in a pleading, in and out of the court, 
actively or passively performed intended to embarrass court's authority and dignity or prevent court officer from performing judicial process. With regard to this, Oemar Senoadjie states that criminal act of contempt of court is addressed to or facing with "administration of justice", rechtpleging (judicial process).[3]

Contempt of Court is set forth in the new RKUHP. This provision of Criminal Act on Judicial Process is available in Book II Chapter VI, set forth in four sections consisting of 17 Articles. The provision which specifically sets forth criminal act of contempt of court is, on one hand, a good effort to maintain judicial agency's authority which is currently not deemed respectable by the community and to realize legal certainty in such criminal act regulation, so that there will be no interpretation of law of article on which a claim is made to committing party faced in law enforcement on criminal act of contempt of court. The provisions of contempt of court in RKUHP set forth in Chapter VI on Criminal Act on Judicial Process may, in the author's opinion, cause problems to the community, advocates and or other justice seekers in case they are merely used to strengthen judge's authority.

In author's opinion, the provisions of contempt of Court in the RKUHP do not comply with substantive legal aspect, but accentuates judges' interest instead without considering and pay attention to the rights of other law enforcers who are struggling for legal justice in the court. The example is the provision of Article 281 RKUHP which imposes criminal fine for maximum category II to anyone who during the course of court hearing does not abide by court order rendered for the purpose of judicial process or does not pay respect to judge or court or attacks judge's integrity in court hearing, or without permission records, publicizes directly or allows publication of hearing process. The provisions of contempt of court in this RKUHP mostly may lead to judges' unlimited power in judicial process in Indonesia since they may easily declare a criminal act on judicial process as contempt of court. The issue above may cause problems in various aspects, such as deprivation of justice seekers' rights, and thus the problems the author is going to discuss are:

a. How is the regulation of criminal act of contempt of court in the national criminal legal system?

b. Is contempt of court regulation in RKUHP necessary?

\section{Discussion}

\subsection{Regulation of Criminal Act of Contempt of Court in the National Criminal Legal System}

The Indonesian criminal justice system explains that court as the institution which determines judicial process, both in criminal and civil cases, needs judge's independence in rendering order. Any act which does not respect court, insults and prevent judicial process, or any unlawful acts may be categorized as contempt of court. The term contempt of court is actually still a violation in judicial process in general since contempt of court may be divided into civil contempt and criminal contempt, direct contempt and indirect contempt.

a. Civil contempt means a party's reluctance to perform its obligations to the other party and does not tend to insult the court, while Criminal Contempt is classified by Barda Nawawi Arief into the following forms and scopes:

1. Interruption before the court or inside the court hearing room;

2. Act taken to influence impartial judicial process;

3. Act which may embarrass or lead to court scandal; 
4. Disturb court officer;

5. Revenge for acts during the course of judicial process;

6. Violation of obligations by court officer;

7. Violation by attorney

b. Direct contempt means act directly performed before the court or around the court environment for the purpose of preventing or disrupting orderly judicial process. Meanwhile, Constructive (indirect) contempt means contempt of court existing outside the court. Such act is commonly intended to challenge court administration by doing or not doing something.

In Indonesia, many and various acts may be categorized as contempt of court, which are set forth in the Criminal Code (KUHP) and non-Criminal Code. A relatively interesting contempt of court cases have ever occurred as the result of Adnan Buyung Nasution, SH's act in 1986 during legal assistance with Letnan Jendral H.R. Dharsono who is accused of committing criminal act of subversion. As the result of act of insulting judicial process in Indonesia, Adnan Buyung Nasution is rendered guilty in the District Court of Central Jakarta with injunction of proposal for revocation of advocate's practice permit to Minister of Justice of the Republic of Indonesia.

The District Court of Purwakarta in Decision Number: 241/Pid.B/2006/PN.PWK has also rendered an order on criminal act of contempt of court on the accused Utih Kusumadi since he has imposed his will to the judges to adjudicate the case. The suspect Utih Kusumadi's act is deemed objectionable act and insult to the judges in the hearing, in violation of Article 335 Paragraph (1) KUHP in conjunction with Article 310 Paragraph (1) KUHP and categorized as contempt of court.[4] The legal principle in decision Number: 241/Pid.B/2006/PN.PWK implies that the accused's act of forcing a judge in the hearing to adjudicate the accused's case is deemed a non-rightful act which is contrary to Criminal Procedure regulating hearing procedure, in violation of Article 217 KUHAP in conjunction with Article 218 KUHAP, thus the judges declare the accused guilty as committing criminal act of contempt of court. The panel of judges' consideration of the accused Utih Kusumadi's act as violation of contempt of court is that the accused Utih Kusumadi has legally and conclusively committed criminal act of challenging the judge's power since he forces the judges in a non-rightful manner to hold the hearing, and therefore the judges render criminal imprisonment to Utih Kusumadi for one year. The Supreme Court of the Republic of Indonesia as the Judex Jurist justifies the Panel of Judges' Decision of the District Court of Purwakarta, since the definition of contempt of court used by the panel of judges of District Court of Purwakarta as declared by the Supreme Court is a progressive legal finding on the basis of Article 5 Paragraph (1) Act Number 48 of 2009 on Judicial Power stating that judges and constitutional court judges are required to explore, follow, and understand legal values and sense of justice existing in the community. Therefore, based on the provisions, judges are obligated to find new law and interpret legislation for the purpose of case they are examining.

The problem to the author is that until now, in the Indonesian criminal legal system, there are many Acts and articles may qualify contempt of court, both in KUHP and non-KUHP. KUHP has set forth articles on contempt of court, in Article 207, Article 210 Paragraph (1) and Paragraph (2), Article 212, Article 216 Paragraph (1), Article 217, Article 220, Article 221, Article 223, Article 224, Article 231, Article 232, Article 233, Article 242 Paragraph (1) and Paragraph (2), Article 316, Article 317, Article 393 bis, Article 420 and Article 522. In addition, act of contempt of court is also set forth in non-KUHP, in Act Number 31 of 1999 in conjunction with Act Number 20 of 2001 on Eradication of Criminal Corruption, Act Number 21 of 2007 on Eradication of Criminal Human Trafficking, Act Number 35 of 2009 on 
Narcotics, Act Number 8 of 2010 on Prevention and Eradication of Criminal Money Laundering, and Government Regulation in Lieu of Law Number 1 of 2002 on Eradication of Criminal Terrorism which has been stipulated as Act Number 15 of 2003.[1]

Besides, the categories of act of contempt of court are also set forth in Act Number 48 of 2009 on Judicial Power and Act Number 3 of 2009 on the Supreme Court (MA). In the author's opinion, the regulation of acts which may be classified into contempt of court in those provisions of law shows that the national criminal legal system is unable yet to reach any criminal acts commonly referred to as contempt of court. Although interpretation of law as may be found in Decision of District Court of Purwakarta Number: 241/Pid.B/2006/PN.PWK may be deemed as temporarily fill the vacancy of law on act of contempt of court, but the legal certainty aspect of the panel of judges' decision in using such interpretation of law is not part of ius constitutive or positive law which may be used as the basis of legal certainty in law enforcement of contempt of court at a later date. Some new law stipulations qualifying criminal acts on judicial process (contempt of court) have currently been included into RKUHP in Book II, CHAPTER IV, such as:[2]

a. Legal advisor who in his work gives legal assistance, negotiates with the adverse party of the party he gives his assistance to, while it is reasonable to know that such act may harm the interest of the party he gives his assistance to.

b. Legal advisor who in his work gives legal assistance to have the party he gives his assistance to winning asks reward intending to influence unlawfully witnesses, expert witness, language expert, investigator, general prosecutor or judge in the concerned party's lawsuit.

c. An individual who represents other as participant or assistant in criminal act, thus is rendered criminal sanction and undergoes such sanction for other.

d. An individual who insults judge's integrity in performing judicial duties or attacks the integrity or impartiality of a judicial process.

e. An individual who publicize or allows publication of anything which may influence impartiality of a judicial.

f. Any witness and other person related to criminal terrorism, corruption, human rights or money laundering that mention reporter's name or address or other matters which may allow identification of reporter's identity in investigation and examination in court hearing are subject to criminal imprisonment for maximum 1 (one) year.

Provisions that specifically set forth criminal act of contempt of court in the RKUHP above is, on one hand, a good effort to maintain judicial agency's authority and realize legal certainty in regulation of criminal act of contempt of court, so that there will be no interpretation of law of article on which a claim is made to committing party faced in law enforcement on criminal act of contempt of court. Based on the formulation on contempt of court in the RKUHP above, it is noticeable that contempt of court protects court legal enforcers more, particularly judges. Contempt of Court should not only protect court legal enforcers, since legal enforcers are not only judges, but also general prosecutor, legal advisor and other parties concerned in a judicial process.

The provisions of contempt of court in RKUHP in Chapter VI on Criminal Act on Judicial Process, in the author's opinion, may cause problems in the community, particularly advocates or legal advisors and or other justice seekers in case the provisions of criminal act of contempt of court merely strengthens judges' authority, which nota bene have strong position in judicial process. Contempt of Court provisions in the RKUHP are evidently deemed not meeting with the substantive legal aspect, that RKUHP regulation accentuates judges' interest only without paying attention to and considering other legal enforcers' rights in the court. For example 
provisions in Article 281 RKUHP which impose criminal fine for maximum category II that whoever during the course of court hearing does not abide by court (judge's) order issued for the purpose of judicial process, or does not respect judges or the court or attack judges' integrity in court hearing, or without court's permission records, publicizes directly or allows publication of hearing process. These provisions will lead to judges' unlimited power in judicial process since this may deem as in violation of contempt of court any legal enforcer who does not abide by them, while for the purpose of formal and material proofs in law enforcement process, precaution is necessary so that there is quite possible judicial process between legal enforcers including between judges and advocates which may potentially lead to new criminalization in criminal act of contempt of court. Journalist profession in their reporting duties in the court as well as interviewees as social control for the court may be potentially subject to criminal sanction based on the new criminal act in the RKUHP. The provisions regulating contempt of court di RKUHP are deemed to silence democracy.

Categories of act of contempt of court have actually been set forth in Act Number 48 of 2009 on Judicial Power, and Act Number 3 of 2009 on the Supreme Court (MA), thus provisions of contempt of court in the RKUHP indeed seem exaggerated, moreover mass media have had rules in reporting in Act Number 40 of 1999 on Press and Journalistic Code of Conduct. An attorney of LBH Pers Gading, Younggar Ditya, states that there is confusion in beleid regulating contempt of court in the RKUHP, since anyone able to assess reporting may influence judges' independence in hearing process. Therefore, Younggar Ditya states that articles related to contempt of court in the RKUHP may potentially cause concern for journalists since such beleid has multiple interpretations and is subjective.

\subsection{Is Contempt of Court regulation in RKUHP necessary?}

The Indonesian legal system currently has no codified and integrated Law of Contempt of Court, although rules of contempt of court have been many found in other regulations and laws, but they do not regulate definitively, specifically and completely. The contempt of court regulation in the Indonesian criminal legal system basically has 2 (two) main objectives, namely:

a. Maintain court's effectiveness and power.

b. Protect and implement parties' rights by forcing to abide by court decision and order.

The Supreme Court has initiates arranging law of contempt of court in maintaining judicial agencies' honor and dignity from non-judicial party's intervention, as confirmed in General Explanatory Note to Act Number 14 of 1985 on the Supreme Court item 4 paragraph 4 which explicitly shows desire to regulate contempt of court specifically. According to Lawrence M. Friedman, whether or not law enforcement is effective and successful depends on three elements of legal system, namely legal structure, legal substance and legal culture. Legal structure is related to law enforcement officers, legal substance covers statutory instruments and legal culture covers living law adopted in a community.[5]

According to Prof. Sudarto, in arrangement of regulation which is part of criminal policy, there are 3 (three) definitions of criminal policy, namely narrow, wide and widest definitions. Narrow definition of criminal policy is the reaction of criminal violation of law. Wide definition of criminal policy is the function of law enforcers in enforcing legal justice, including court and police working procedure. With regard to the widest definition of criminal policy, Prof. Sudarto takes Jorgen Jespen's definition, which is whole policy made through legislation and official agencies, aiming at enforcing the community's norms. 
Regulation of contempt of court principally requires further arrangement in codified and integrated regulations and laws in Indonesia. The RKUHP has set forth provisions of contempt of court deemed to enforce law in Indonesia, particularly to maintain court's dignity. However, will rules of contempt of court in the RKUHP give sense of justice to all litigants? Not all legal disputes run well, since they start with problems which cannot be settled amicably. Rules of contempt of court in RKUHP evidently only protect judges' interest, while they are not the only party in proceeding, but there are other parties such as general prosecutor, legal advisor, and other concerned parties. Therefore, if contempt of court only protects judges' interest, it will not lead to legal justice for all parties and other legal enforcers.

Contempt of court in the RKUHP has been included into Criminal Act on Judicial Process as set forth in Book II, Chapter VI, consisting of four sections and 23 articles. Section One on Disturbance on and Misdirection of Judicial Process has Article 281 and Article 282. Section Two on Prevention of Judicial Process has Article 283, Article 284, Article 285, Article 286, Article 287, Article 288, Article 289, Article 290, Article 291, Article 292, Article 293, Article 294, Article 295 and Article 296. Section Three on Destruction of Building, Hearing Hall and Equipment of Court Hearing has Article 297. Finally, Section Fourt on Protection of Witness and Victim has Article 298, Article 299, Article 300, Article 301, Article 302 and Article 303.[6]

The author argues that contempt of court in the RKUHP contains articles which only grant unlimited power to judges, such as judges may declare an act of contempt of court on anyone who during the course of a court hearing does not abide by judge's order issued for the purpose of judicial process, anyone who behaves disrespectfully to judges or attacks judges' integrity in a court hearing, or without permission records, publicizes or allows publication of court hearing. Or, in other provisions, a judge may declare as an act of contempt of court with criminal imprisonment for maximum 5 (five) years or criminal fine for maximum category $\mathrm{V}$, an advocate who performs his duties fraudulently, such as making agreement with client's opposing party while knowing or reasonably expecting that such act may harm the client's interest, or act of influencing clerk, general prosecutor or judge in a case with or without reward.

Such contempt of court regulations do not cause sense of justice in the community, since in seeking for justice, differences in principle may occur, which may lead to commotion between justice seekers or even with judges. In such condition, judges may declare as an act of contempt of court when they are deemed disrespectful to judges or the court or attack judge's integrity in a court hearing. With regard to this, the Chairman of DPP PERADI, Luhut Pangaribuan, states that the impacts of contempt of court may lead to excessive criminalization, thus in contempt of court regulation, PERADI desires a balance which will benefit all parties. Luhut Pangaribuan in this case stats that factually, right now, many judges are examined by Judicial Commission since they violate judges' ethics and moral and or many judges or court officers are still investigated and caught by the Corruption Eradication Commission (KPK) since they have committed criminal corruption. Therefore, overseeing court power (judges) is more important than contempt of court, since in current national criminal legal system, when in a hearing judges state that a person has undermined court's authority, they may discharge him or order the General Prosecutor to drive him away, thus judges' power in current national criminal legal system is very great and it is unnecessary to strengthen it through contempt of court regulation. Meanwhile, other acts which may be declared as contempt of court on anyone who without permission records, publicizes directly, or allows publication of hearing process is deemed to silence democracy, of which matter has been stated by a Researcher from MaPPI FH UI, Ditta Wisnu, in CNN Indonesia. According 
to Ditta Wisnu, act of contempt of court which may be addressed to press professionals in their reporting duties is contradictor to Act Number 40 of 1999 on Press and Journalistic Code of Conduct, thus Ditta states that articles of contempt of court should not be set forth in RKUHP.[7]

The author agrees with the idea that contempt of court should be set forth in regulations and laws since it serves as legal protection and for legal certainty for non-interpretation of law in order to keep court's dignity. Interpretation of law will cause legal uncertainty, which will harm the interest of concerned parties or other legal enforcers. Regulation of contempt of court should have more extensive definition, and should not only protect judges' interest, but also the interest of other legal enforcers in court.

\section{Conclusion}

a. In the national criminal legal system, provisions of contempt of court have had no codified and integrated legal regulation, since such provisions of contempt of court are still distributed in KUHP and non-KUHP.

b. RKUHP requires contempt of court regulation for legal certainty so that it will not cause interpretation for law in the practice of contempt of court enforcement.

\section{References}

[1] Padmo Wahjono, Contempt of Court Dalam Proses Peradilan Di Indonesia, dalam Majalah Hukum dan Pembangunan No.4 Th. XVI, Agustus 1986, hlm. 38

[2] Wahyu Wagiman, Contempt of Court Dalam Rancangan KUHP, dalam Position Paper Advokasi RUU KUHP, September 2005, hlm. 7

[3] Oemar Seno Adji dan Indriyanto Seno Adji, Peradilan bebas dan contempt of court, Jakarta: Diadit Media, 2001, hlm. 210.

[4] Susanto Nugroho, "Pengaturan Tindak Pidana Contempt of Court Berdasarkan Sistem Hukum Pidana Indonesia”. Diponegoro Law Journal. Vol.6 No.2, 2017, hlm. 10

[5] Lawrence M. Friedman, Sistem Hukum Perspektif Ilmu Sosial, Bandung: Nusa Media, hlm. 15

[6] Dewan Perwakilan Rakyat Republik Indonesia, Rancangan Undang-undang Republik Indonesia tentang Kitab Undang-undang Hukum Pidana, Jakarta, September 2019, hlm. 65-70.

[7] Feri Agus., "Pasal Contempt of Court di RKUHP Dinilai Bungkam Demokrasi”, CNN Indonesia, Rabu, 14 Februari 2018, hlm 1. 